\title{
The Determination of the Needs of the Families with a Mentally Handicapped Child According to Their Mood
}

\author{
Esat Sanli \\ Ondokuz Mayıs University, Turkey \\ Yasar Barut \\ Ondokuz Mayıs University, Turkey
}

\section{Introduction}

For most families who faced with their child's handicap, it may be difficult to accept this handicap of their child while they are expecting a healthy, lovely child (Huang, Kellet \& John, 2009; p.1214; Wong, Chan, Cardoso, Lam, Miller, 2004; p. 143 ). Many families with this situation intensely experience the feelings such as fear, anxiety about the future and their child's condition ( Buran, Sawin, Grayson, \& Criss, 2009; p. 91, Öztürk, 2011; p. 25, Russel, 2003; p. 144). As a result, mother and father usually experience a psychological imbalance.

To have a handicapped child brings some special feelings, expectations, concerns and needs along about the children's special condition. To live with a handicapped child may affect mother and father, siblings and the other members of the extended family (Reichman, Corman \& Noonan, 2008; p. 680; Russel, 2003; p. 144). While these special situations appear with almost all the families who have a handicapped child, the intensity of the mentioned situations can change from familt to family, even from person to person in the same family.

We can talk about various factors which affect the families' fulfilling their coping capacity about the problems they face related to child's handicap. The mother and father's personal characteristics, marital adjustments, religious believes, socioeconomic level, the environmental features of the family are some of these. Besides, the child's sex, the level of his/her hndicap can be among the reasons which can affect the family's psychosocial situation ( Reichman and others, 2008; Cavkaytar, 2010; p. 23, Lüle, 2008, p. 29) 
While a child without a handicap who passed normal stages of development helathfully brings an economical responsibility to the family, the handicapped children's health, nursing etc. expenses bring a bigger economical responsibility (Sar1, 2007). While families' anxiety, depression, stres levels increases, low selfesteem can be a matter due to some situations such as not meeting the needs of the child and the family. In addition to this, there can be a breakdown in marriage relationship and a decrease in personal harmony (Girli, Yurdakul, Sarısoy, Özekeş, 1998; p.2)

In families with mentally handicapped children, the life turns around the needs of the handicapped child most of the time. The child's handicap may affect the family's working condition. The mother and father may have to stay at home for the child's nursing and thus, they may have to decrease the working hours or leave the job (Viner-Brown \& K. Kim, 2005; p. 65) Mothers usually take more responsibility in meeting the child's nursing needs. This responsibility sometimes affects the mother negatively, increasing stress may reflect on the husband and the other children. Thus, there occur marriage problems and the handicapped child's adaptation and behavioral problems against his/her healthy siblings (Küçüker,1993; Küllü, 2008 ), these negative factors induce another stres factor and put the family in a vicious circle.

Mental disability is a nonconvertible and continuous situation in general. Thus, meeting the needs of the mentally handicapped child leads to continuous and mostly hard periods for mother and father. The disabled child's needs, education, cumulative material needs, social attitudes and judgements about the handicap and uncertanities about the child's present and future situations are the reasons of the stress for the family. If the family couldn't manage to cope with all these stres factors, the cumulative and gradually increasing effects of the experienced stress might cause emotional problems such as fear and anxiety ( Dereli \&Okur , 2008; Çapa, 2009; Karadağ, 2009)

Numerous domain experts who provide service to disabled individuals have focused on only disabled children for many years and the family has not generally dwelled on during this time. But today, it is more clearly seen that meeting the needs of family means meeting the needs of the child (Kaner, 2009, p. 29). In the recent studies on the field of special education, the importance of determining the needs of the parents and the other family members instead of providing the education and support services only to the handicapped child is emphasized (Şardağ, 2010) For the services' to be given to the handicapped child reach the goal, to provide several education and support services, first of all, the needs of the family, the family functions, the marital dynamics, the compulsions experienced by 
Esat Shanli, Yashar Barut

the family, the coping mechanisms, the internal and external support sources it owns and the interaction of all these factors must be examined multidemensionally ( Kaner, 2004)

The families' needs arising from the child's handicap are seem to differ in terms of the handicap's type, acuteness, the child's age. Thus ,each family with a handicapped child has different problems (Reichmann and others, 2008; Sucuoğlu, 2009, p. 378; Evcimen, 1996; p. 15 ). The needs of the families have been classified diversely based upon the research resultp. In general, material needs include basic needs such as nutrition, clothing, hosehold expenses, transportation expeses and specific material needs such as the children's health expenses (Bailey and Simeonsson, 1988, p. 119). The need of explaining to the community includes the matters of explaining their child's disability case to the others and to be able to make an explanation about what kind of a stuation it is to be the parent of a handicapped child (Bailey \& Simeonsson, 1988, p. 119; Warner; 2006; p. 4 ). For the families with a handicapped child, the information need, how to teach their child and how to interact with him/her, or the information needs about how to reach the present and the future services for their handicapped child are among the highly important needs ( Bailey \&Simeonsson, 1988, p. 119, Russel, 2003). General support and social service need along with the experts in public enterprises and offical bodies, coming together with the families of the handicapped children, dialoging with an expert, benefitting from the support of mates, friends, relatives and neighbours and religious officials are among the prior needs of the families with handicapped children ( Bailey \& Simeonsson, 1988, p. 119)

It is quite important to distinguish the families's real needs from the ones that are felt or estimated by the others (Mert, 1997, p. 21). The diversing needs of the families with a handicapped child will be tried to be revealed transparently in the consequence of this study. The fact that families get better special education services and the services are provided and centered in acoordance with the needs will easen the families' fulfilling their responsibilities about their children. Thus, the needs of the families in different areas will be meet, the families will be more saturated in this sense.

The institutions, at the point of being servicer and the needed, might develop a belief that families have to act in accordance with the institution's aims rather than an effort to meet the needs of the families in time (Akoğlu, 2011, p. 31 ). Although the institutions, the educators and various domain experts have several idas about the issues such as the needs of the families with mentally handicapped children, how they feel themselves (Akoğlu, 2011; p. 31), the needs properly can state the truth only when they are the results os the family's own consideration who is the 
source of these needs (Mert, 1997, p. 20 ). And this necessitates an expert apprasial which will be made with a scientific approach towards the needs of the familiep.

In accordance with the evaluations that were made above, this research was made to determine which requirement areas are affected by the mood of parents with a mentally handicapped child attending special education and rehabilitation centers and the level of it.

\section{Methodology}

In this chapter the explanations are given about the population and the sample of the research, data collection tools, statistical methods which were used anlysing the data.

\subsection{Research Design}

In the research, descriptive and relational methods were used to determine the needs of the families whose mentally handicaped children attend special education and rehabilitation centers.

\subsection{Population and sample}

The population of this study consisits of the families of mentally handicapped children who attend special education and rehabilitation centers within the provincial border of Samsun in 2011-2012. The sample consists of 443 ( 249 mothers, 194 fathers) families with handicapped children who were selected via simple random samling method and who attend 14 special education and rehabilitation centers in the provincial border of Samsun, Çarşamba and Bafra districts.

\subsection{Data Collection Tools}

In this study, aimed at the study's goal, personal information form which was developed by the researcher by receiving expert opinion and Family Needs Assesment Survey were used to collect the datum.

\subsubsection{Family Need Assesment Survey ( FNAS )}

It was developed by Bailey and Simeonsson in order to determine the needs of the families in 1988. Family Needs Assesment Survey ( FNAS ) was adapted into Turkish by Sucuoğlu in 1995 after validity and reliability studies were made. Family Needs Assesment Survey (FNAS) consists of 35 items and has got six factor structures in its original forms ( Bailey \& Simeonsson ). Six factors in 
FNAS's original factor structure consists of material needs, the need of explaining to the environment, information need, social services, family-running and support need (Bailey \& Simeonsson). As a result of adaptation study and factor analysis made by Sucuoğlu (1995), 11 items were purged from the survey. FNAS2s validity and reliability studies were examined via different handicap groups and it was cited as valid nd reliable ( Akçamete \& Kargın, 1998; Mert, 1997 ).

In order to make validity and reliability study of FNAS under the changing conditions of it, Cavkaytar, Ardıç, Aksoy (2012) conducted the FNAS to the families whose disabled children have been educated in education practice schools in six provinces of Turkey.

\subsection{Data Collection}

The managers and the founders of 16 special education and reahabilitation centers which service in Samsun city center, Çarşamba, Ondokuz Mayıs, Bafra counties which are subsidary to Samsun were interviewed, the aim of the research was stated clearly. Two of these institutions stated that they would not be able to help, the study was made with 14 institutions. In this direction personal information form and the Family Needs Assesment Survey was reached 870 families with handicapped children who attend the institutions. Data collection tools were conducted to illiterate families by researcher or the institution's psychological counselor or psychologist. 24 of the 467 forms which turned back from the families weren't included into the anlysis since they would not be able to to be evaluated wholesomely. Thus, the datumwich were achieved from 443 forms constituted the data sourse of the study.

\subsection{Data Anlaysis}

In order to examine the tested hypothesis in the research, One- way Analysis of Variance was made. One of the multiple comparison tests,the Duncan test, was used to determine from which groups the discussed significance derives in the cases where the difference is significiant between the avarages. $p<.05$ was taken as significiant (important) statistically. All the acquired datum were analysed via using SPSS 17.0 package. The findings that were achieved as a result of the anlysis of the datum are given in the findings chapter in an order which can be an answer to the sub-problems and the hypotheses of the research. 


\section{Findings}

The statistical analysis results that were mad efor FNAS subscales in order to detemine in which areas the needs of the families differ according to mother and fathers' moods.

\subsection{Material Need}

When the Material Need Subscale is eaxamined according to mother and fathers' mood, It is seen that the point averages of the mothers with uneasy mood are higher than the other mothers', mothers with anxious and relaxed mood are foolowing this group. When the numeric datum aimed at the fathers is eaxamined, it is seen that fathers with uneasy mood have higher point averages of Material Need Subscale than other fathers do, this was being followed respectively by the fathers with anxious and relaxed mood.

To test whether there is a statistically significantin the applied one-way ANOVA on the data of these observed differences and the results are given in Table 1.

Table 1:One-way analysis of variance results of Financial Requirements Subscale scores according to the parents' mood.

\begin{tabular}{|c|c|c|c|c|c|c|}
\hline $\begin{array}{l}\text { Position } \\
\text { in the } \\
\text { Family }\end{array}$ & $\begin{array}{c}\text { The Source of } \\
\text { Variance }\end{array}$ & $\begin{array}{l}\text { Sum of } \\
\text { Squares }\end{array}$ & $\mathrm{Sd}$ & $\begin{array}{c}\text { Average of } \\
\text { Squares }\end{array}$ & $\mathrm{F}$ & $\mathrm{p}$ \\
\hline \multirow{3}{*}{ 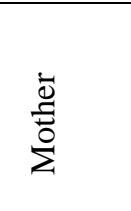 } & Intergroup & 96,171 & 2 & 48,085 & 3,272 & ,040 \\
\hline & Within Groups & 3615,114 & 246 & 14,696 & & \\
\hline & Total & 3711,285 & 248 & & & \\
\hline \multirow{4}{*}{ 离 } & $\begin{array}{c}\text { The Source of } \\
\text { Variance }\end{array}$ & $\begin{array}{l}\text { Sum of } \\
\text { Squares }\end{array}$ & $\mathrm{Sd}$ & $\begin{array}{c}\text { Average of } \\
\text { Squares }\end{array}$ & $\mathrm{F}$ & $\mathrm{p}$ \\
\hline & Intergroup & 236,980 & 2 & 118,490 & 7,914 & ,001 \\
\hline & Within Groups & 2829,848 & 189 & 14,973 & & \\
\hline & Total & 3066,828 & 191 & & & \\
\hline
\end{tabular}

In one-way analysis of variance results, difference wasfound to be significant both for mothers $[F(3,272), p<.05]$, and for fathers $[F(7,914), p<.001]$. In order to 
determine which groups these differences that arise from, in Duncan test resultdone on average scores of mothers' and fathers' Financial Requirements subscales; the difference between average Financial Requirements subscales scores of the mothers feel herself anxious with the mothers feel herself comfortable/relax; the mothers feel herself uneasy/restlesswith the mothers feel herselfcomfortable/relaxwas found to be significant. In addition, the difference between average Financial Requirements subscales scores of the fathers feel himselfanxious with the fathers feel himselfcomfortable/relax, the fathers feelhimself uneasy/restlesswith the fathers feel himselfcomfortable/relaxwas found to be significant.

\subsection{Environment Description Need}

Looking at the average Environment Description Requirement Subscale scoresaccording to theparents' mood, mothers -with restless/uneasy mood- have higherthe average Environment Description Requirement Subscale scores than the other mothers, this is followed by the mother with anxious and relaxed mood, respectively have been seemed. Considering the numerical data for the fathers,fathers -with restless/uneasy mood- have higher the average Environment Description Requirement Subscale scores than the other fathers, this is followed by the father with anxious and relaxed mood, respectively have been seemed. To determine whether there is significant inter-group difference One-way analysis of variance results are given in Table 2.

Table 2: One-way analysis of variance results of Environment Description RequirementSubscale scores according to the mothers' mood.

\begin{tabular}{|c|c|c|c|c|c|c|}
\hline $\begin{array}{l}\text { Position in } \\
\text { the Family }\end{array}$ & $\begin{array}{c}\text { The Source of } \\
\text { Variance }\end{array}$ & $\begin{array}{l}\text { Sum of } \\
\text { Squares }\end{array}$ & $\mathrm{Sd}$ & $\begin{array}{l}\text { Average of } \\
\text { Squares }\end{array}$ & $\mathrm{F}$ & $\mathrm{p}$ \\
\hline \multirow{3}{*}{$\begin{array}{l}\dot{ \pm} \\
\stackrel{\Xi}{0} \\
\stackrel{\Sigma}{\Sigma}\end{array}$} & Intergroup & 232,702 & 2 & 116,351 & 5,972 & ,003 \\
\hline & Within Groups & 4792,584 & 246 & 19,482 & & \\
\hline & Total & 5025,285 & 248 & & & \\
\hline \multirow{4}{*}{ 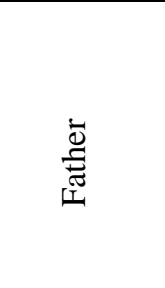 } & $\begin{array}{c}\text { The Source of } \\
\text { Variance }\end{array}$ & $\begin{array}{l}\text { Sum of } \\
\text { Squares }\end{array}$ & $\mathrm{Sd}$ & $\begin{array}{l}\text { Average of } \\
\text { Squares }\end{array}$ & $\mathrm{F}$ & $\mathrm{p}$ \\
\hline & Intergroup & 452,274 & 2 & 226,137 & 13,479 & ,000 \\
\hline & Within Groups & 3170,970 & 189 & 16,778 & & \\
\hline & Total & 3623,245 & 191 & & & \\
\hline
\end{tabular}


One-way analysis of variance results shows that for the mothers $[F(5,972), p$ $<.05]$, for the fathers [F (13.479), $\mathrm{p}<.001]$ the difference is significant. In Duncan test result which is done in order to determine which groups these differences that arise from: the difference between average Environment Description Requirement subscales scores of the mothers feel herself anxious with the mothers feel herself comfortable/relax; the mothers feel herself uneasy/restless with the mothers feel herself comfortable/relax was found to be significant. In addition, the difference between average Environment Description Requirements subscales scores of the fathers feel himself anxious with the fathers feel himself comfortable/relax, the fathers feel himself uneasy/restless with the fathers feel himself comfortable/relax was found to be significant.

\subsection{Information Need}

Comparing the average Information Requirement Subscale scores according to the parents' mood, mothers -with anxious mood- have higher the average Information Requirement Subscale scores than the other mothers, this is followed by the mother with restless/uneasy and relaxed mood, respectively have been seemed. Considering the numerical data for the fathers, fathers -with restless/uneasy moodhave higher the average Information Requirement Subscale scores than the other fathers, this is followed by the father with anxious and relaxed mood, respectively have been seemed. To determine whether there is significant inter-group difference One-way analysis of variance results are given in Table 3.

Table 3: One-way analysis of variance results of Information Requirement Subscale scores according to the mothers' mood.

\begin{tabular}{|c|c|c|c|c|c|c|}
\hline $\begin{array}{l}\text { Position in } \\
\text { the Family }\end{array}$ & $\begin{array}{c}\text { The Source of } \\
\text { Variance }\end{array}$ & $\begin{array}{l}\text { Sum of } \\
\text { Squares }\end{array}$ & $\mathrm{Sd}$ & $\begin{array}{l}\text { Average of } \\
\text { Squares }\end{array}$ & $\mathrm{F}$ & $\mathrm{p}$ \\
\hline \multirow{3}{*}{$\begin{array}{l}\bar{d} \\
\stackrel{\tilde{0}}{\Sigma} \\
\dot{\Sigma}\end{array}$} & Intergroup & 394,961 & 2 & 197,481 & 7,399 & ,001 \\
\hline & Within Groups & 6565,424 & 246 & 26,689 & & \\
\hline & Total & 6960,386 & 248 & & & \\
\hline \multirow{4}{*}{ 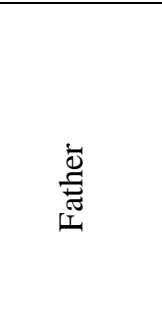 } & $\begin{array}{c}\text { The Source of } \\
\text { Variance }\end{array}$ & $\begin{array}{l}\text { Sum of } \\
\text { Squares }\end{array}$ & $\mathrm{Sd}$ & $\begin{array}{l}\text { Average of } \\
\text { Squares }\end{array}$ & $\mathrm{F}$ & $\mathrm{p}$ \\
\hline & Intergroup & 382,158 & 2 & 191,079 & $\begin{array}{c}13,47 \\
9\end{array}$ & ,000 \\
\hline & Within Groups & 4469,337 & 189 & 23,647 & & \\
\hline & Total & 4851,495 & 191 & & & \\
\hline
\end{tabular}


As a result, the difference for both the mothers [F (7,399), $\mathrm{p}<.001]$, and for fathers [F (13.479), $\mathrm{p}<.001]$ was found to be significant. In Duncan test result which is done in order to determine which groups these differences that arise from: the difference between average Information Requirement subscales scores of the mothers feel herself anxious with the mothers feel herself comfortable/relax; the mothers feel herself uneasy/restless with the mothers feel herself comfortable/relax was found to be significant. In addition, the difference between average Information Requirements subscales scores of the fathers feel himself anxious with the fathers feel himself comfortable/relax, the fathers feel himself uneasy/restless with the fathers feel himself comfortable/relax was found to be significant.

\subsection{General Support and Community Service Need}

Looking at the average General Support and Community Service Requirement Subscale scores according to the parents' mood, mothers -with anxious moodhave higher the average General Support and Community Service Requirement Subscale scores than the other mothers, this is followed by the mother with restless/uneasy and relaxed mood, respectively have been seemed. Considering the numerical data for the fathers, fathers -with restless/uneasy mood- have higher the average General Support and Community Service Requirement Subscale scores than the other fathers, this is followed by the father with anxious and relaxed mood, respectively have been seemed. To determine whether there is significant intergroup difference One-way analysis of variance results are given in Table 4.

Table 4: One-way analysis of variance results of General Support and Community Service Requirement Subscale scores according to the parents' mood.

\begin{tabular}{|c|c|c|c|c|c|c|}
\hline $\begin{array}{l}\text { Position } \\
\text { in the } \\
\text { Family }\end{array}$ & $\begin{array}{c}\text { The Source of } \\
\text { Variance }\end{array}$ & $\begin{array}{l}\text { Sum of } \\
\text { Squares }\end{array}$ & $\mathrm{Sd}$ & $\begin{array}{c}\text { Average of } \\
\text { Squares }\end{array}$ & $\mathrm{F}$ & $\mathrm{p}$ \\
\hline \multirow{3}{*}{$\begin{array}{l}\dot{0} \\
\frac{0}{0} \\
\dot{\Sigma}\end{array}$} & Intergroup & 77,695 & 2 & 38,848 & 2,799 & ,063 \\
\hline & Within Groups & 3414,288 & 246 & 13,879 & & \\
\hline & Total & 3491,984 & 248 & & & \\
\hline \multirow{4}{*}{ 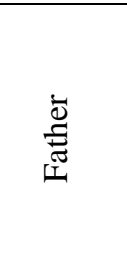 } & $\begin{array}{c}\text { The Source of } \\
\text { Variance }\end{array}$ & $\begin{array}{l}\text { Sum of } \\
\text { Squares }\end{array}$ & $\mathrm{Sd}$ & $\begin{array}{c}\text { Average of } \\
\text { Squares }\end{array}$ & $\mathrm{F}$ & $\mathrm{p}$ \\
\hline & Intergroup & 220,454 & 2 & 110,227 & 7,914 & ,001 \\
\hline & Within Groups & 2632,541 & 189 & 13,929 & & \\
\hline & Total & 2852,995 & 191 & & & \\
\hline
\end{tabular}


One-way analysis of variance had been showed that the difference for mothers meaningless [F (2,799), $\mathrm{p}>$.05], and meaningful for fathers [F (7.914), $\mathrm{p}<.001]$.In Duncan test result which is done in order to determine which groups this difference that arise from: the difference between average General Support and Community Service Requirement subscales scores of the fathers feel himself anxious with the fathers feel himself comfortable/relax; the fathers feel himself uneasy/restless with the fathers feel himself comfortable/relax was found to be significant.

\section{Discussion And Comments}

The findings obtained from the analyses are examined, 59\% anxious, 24\% restless/uneasyand $17 \%$ comfortable/relax mood of 441 parents, also observed that requirements are differentiated according to the parents' mood. Parents' average scores obtained from four sub-scales are differentiated according to parents' mood. It has been seen that the parents feel themselves comfortable/relax indicate lessrequirements than the parents feel anxious and restless/uneasy in the four requirement areas are assessed by AGBA. This finding of the research supports the hypothesip.

The intellectual disability children's being different from peers, dependency level and the continuity of hamper can cause the feelings of inadequacy in parents, the time increase in the workload of care,the restriction of their social life, physical problems such as pain and fatigue, decreasing in quality of life (Aktaş, 2010; p. 67). Aktaş's study is also indicated that most of the parents are anxious about and afraid of losing their child.

Küllü (2008), in his study to assess the depression status of parents with disabled children has reached the conclusion that in approximately one-third of parents with disabled children have moderate or severe depressive symptomp. In Kilıç's study (2009; p. 85), 62.1\% of caregivers of children with physical disabilities (parentscaregivers) have demonstrated that they showed symptoms of mental illness requiring treatment. Also the results of the study include that $68.4 \%$ of the mothers are living in fear about the future of their child. Danseco (1997; p. 268), suggesting that mothers are particularly worried about the academic development of children with disabilitiep. In Duman's study (1995; p. 198), it has been found that being in need of constant care and they can't give exactly expected from their age can cause increasing in the concern of parentp.

There is an intense relationship between the requirement and concern. anxiety in an individual (Güngör, 2008; p. 11) to overcome anxiety is a feeling in the area of 
state requirements for individuals over time. So in this work, not saturated requirements can cause $59 \%$ of the familyexpress themselves as anxioup. On the other hand it is cause for concern for many low income families who have to be spending a lot of material about the situation of children may have been caused to specify more requirements in this regard. Similarly, Duman (1995; p. 200) concluded that low income cause increasing concerns on various issues in families with mentally handicapped children.

Even for families with similar socio-economic conditions It can be said that worry directs to feelmore requirementp. In the study by Farmer, Marien, Clark, Sherman, Selva (2004; p. 363); the mothers, feel having more responsibility and difficulty on themselves, can't find the reaching power to the support and services needed with negative effects of this kind of feelingp. Similarly, Huang et al (2009; p. 1218) it has been concluded that failing to have reached the needed support and services is a factor that triggers negative feelings for the child and the family. It can be considered that the families feel themselvesanxious and restless/uneasy mood are more passive in meeting the requirements compared with the families feel comfortable/relax as a result of the families' feeling of weaknesp. This may cause to continue withoutmeeting the requirementp.

Huang and colleagues had been done a study (2009; p. 1218), reveals a conclusion; the mothers entered into a deep despair mood and negative emotions when they noticed the children's obstaclep. Their negative feelings are the reasons for the unrest/uneasiness for parentp. This situation may lead to need much more general support and more difficulty in theexplanation of the child's disability to the environment in anxious and uneasy/restless parents than comfortable/relax parentp. This difficulty is caused in said space family can be shown as to indicate more intensive requirementp. In addition, Kim, Lee \& Morningstar (2007; p. 259) have demostrated a conclusion; the parents' perceptions of their child's disability and having positive or negative outlook to the future are effected largely from their parentp. Having such a negative attitude in the nearby can be a reason to indicate much more requirements; for an increase in the family's concerns, a failure to meet the necessary requirements and explanation to the environment.

\section{Recommendations}

Thinking the effects of the families' mood on their requirements, it can besuggested an establishment of a family psychological counseling system asin family practice especially for families with disabled children. 


\section{References and notes:}

Akçamete, G., \& Kargın, T. (1996). Determination the Needs of the Parents Having Hearing Impaired Children. Journal of Special Education, 2, 7-24.

Aktaş, E. (2010). Fiziksel Engelli Çocuk ve Ailesinin Evde Bakım Gereksinimine Işıı Tutucu Araştırmalarn Sistematik Incelenmesi[The Systematic Review of The Researches Which Light The Way for Home Care Requirements of Physically Disabled Children and Their Families]. Master Thesis, Marmara University, Institute of Health Sciences, İstanbul, Turkey Bailey JR., D. B., \& Blasco, P. M. (1990). Parents' Perspectives on a Written Survey of Family Need. Journal of Early Intervention, 14(3), 196-203.

Bailey, D., \& Simeonsson, R. (1988). Assessing Needs Of Families With Handicapped Infant. The Journal Of Special education, 22(1), 117-127.

Buran, C. F., Sawin, K., Grayson, P., \& Criss, P. (2009). Family Needs Assessment in Cerebral Palsy Clinic. Journal For Specialists In Pediatric Nursing, 14(2), 86-93.

Cavkaytar, A. (2010). Özel Gereksinimli Çocuğu olan Aileler [Families with Special Needs Children] (Ed. T. Güler). Anne Baba Eğitimi [Parent Training]. Ankara: Pegem A Publishing.

Cavkaytar, A. (2010). Özel Ĕgitimde Aile Eğitimi Ve Rehberliği[Parent Training and Guidence on Special Education]. Maya Akademi.

Çapa, B. (2009). Zihin Engelli ve Otistik Çocuğu olan Ailelerin Toplumsal Hayata Katılmada Yaşadıkları Güçlüklerin Karşılaştırılması_Comparison of Difficulties in Participation to the Community Life of Families Who Have Mentally Retarded and Autistic Child]. Master Thesis, Marmara University, Institute of Educational Science, İstanbul, Turkey

Danseco, E. R. (1997). Building Bridges; African-American Mothers' And Teachers' Ethnotheories On Child development, Child Problems, And Home-School Relations For children With And Without Disabilitiep. University of Maryland, Philosophy.

Dereli, F., \& Okur, P. (2008). Determination of The Depression Level of the Families Having a Handicapped Child. Yeni Tip Dergisi(25), 164-168.

Duman, H. (1995). Zihinsel Engelli Çocuğu olan Anne Babaların Kaygı Düzeylerinin Karşılaştırılarak Çocuğa Yönelik Beklentilerinin Belirlenmesi[Determination of Expectations About the Child by Comparing the Level of Anxiety of Parents who have Mentally Retarded Children]. Master Thesis, Dokuz Eylül University, Institute of Social Sciences, İzmir, Turkey

Evcimen, E. (1996). Zihin Engelli Çocuğu Olan Ailelerin (Anne-Babaların) Gereksinimlerinin Belirlenmesi[Determination of Family (Parents) Needs With Menatl Handicapped Children]. Master Thesis, Anadolu University, Institute of Social Sciences, Eskişehir.

Farmer, J. E., Marien, W. E., Clark, M. J., Sherman, A., \& Selva, T. J. (2004). Primary

Care Supports For Children With Cronic Health Conditions; Identifying and Predicgting Unmet Family Needp. Journal Of Pediatric Psychology, 29(5), 355- 367.

Girli, A., Yurdakul, A., Sarısoy, M., \& Özekes, M. (1998). Zihinsel Engelli ve Otistik Çocukların Anne Babalarına Yönelik Grup Danışmanlığının Depresyon, Benlik Saygısı ve Tutumları Üzerine Etkisi [The Effects of the Group Counselling to meet the Needs of Knowledge and Psychological Support of the Mentally Handicapped and Autistic Children's Parents]. 10. National Congress of Psychology.

Güngör, E. (2008). Özel Ĕgitime Muhtaç Çocukların Anne ve Babalarının Psikolojik İlişki

İhtiyaçları Ile Durumluk Ve Sürekli Kaygı Düzeyleri Arasındaki İlişkiler[Relations Between Requirements for Psychological Relations of Parents of Children Needing Special Education and Their State-Trait Anxiety Levels]. Master Thesis, Selçuk University, Institute of Social Sciences, Konya, Turkey. 
Howard, V.F., Williams, B., Lepper, C.E. (2011) "Ailelerle İlişki Temelli Ekip

Oluşturma" (Trans. Akoğlu, G) in Özel Gereksinimi Olan Küçük Çocuklar Eğitimciler,

Aileler ve Hizmet Verenler İçin Bir Başlangıç (Trans. Ed.: G. Akçamete) [Very Young

Children With Special Needs: A Foundation for Educators, Families, and Service

Providers]. Ankara: Nobel Publishing.

Huang, Y.-P., Kellet, U., \& John, W. (2009). Cerebral Palsy; Experiences Of Mothers After Learning Their Child's Diagnosip. Journal of Advanced Nursing, 1215-1221.

Kaner, P. (2004). Engelli Çocukları Olan Anababaların Alglladikları Stres, Sosyal Destek ve Yaşam Doyumlarının Incelenmesi[Perceived Stres, Social Support and Life Satisfaction in Parents with Disabled Children]. Research Report, Ankara University Scientific Research Projects, Ankara, Turkey.

Kaner, P. (2009). Aile Katılımı Ve İşbirliği [Family Participation and Cooperation]. (Ed.)

Sucuoğlu in, Zihin Engelliler ve Eğitimleri[Mentally Disabled Individuals and Their Educations] (pp. 352-405). Ankara; Kök Publishing.

Karadağ, G. (2009). Hardships Undergone by Mothers with Handicapped Children,

Hopelessness and Social Support From Family. TAF Preventive Medicine Bulletin, 8(4), 315-322.

Kılıç, P. (2009). Fiziksel Engelli Çocuğun Evde Bakım Gereksiniminin Aileye Etkisi[The

Effect of Home Care Needs on the Families of the Physically Disabled Children].

Master Thesis, Marmara University, Institute of Health Science, İstanbul, Turkey.

Kim, K.-H., Lee, Y., \& Morningstar, M. E. (2007). An Unheard Voice; Korean American Parents' Expectations, Hopes, and Experiences Concerning Their Adolescent Child's

Future. Research\&Practice For Persons With Severe Disabilities, 32(4), $\quad$ 253-264.

Küçüker, S. (1993). Özürlü Çocuk Ailelerine Yönelik Psikolojik Danışma Hizmetleri. Ankara

University Faculty of Educational Science Journal of Special

Education, 1(03).

Küllü, Z. (2008). Özürlü Çocuğu olan Ebeveynlerde Depresyon Durumunun Değerlendirilmesi[Evaluating the Depression Status of Parents with Disabled Children]. Master Thesis, Erciyes University Institute of Health Sciences, Kayseri, Turkey.

Mert, E. (1997). Farklı Engel Grubunda Çocuğu Olan Anne ve Babalarının Gereksinimlerinin Karşllaştırlması [A Comparison of the Needs of Parents with Different Handicapped Children]. Master Thesis, Abant İzzet Baysal University, Institute of Social Sciences, Bolu, Turkey

Öztürk, Y. (2011). Engelli Çocuğu olan Ailelerin Gereksinimlerinin Ve Aile Yükünün Belirlenmesi[The Effect of Informing Normal Children Who Continue Kindergarten

on Their Attitudes Towards Their Peers with Mental Retardation]. Master Thesis, Haliç University, Institute of Health Sciences, İstanbul, Turkey.

Reichman, N. E., Corman, H., \& Noonan, K. (2008). Impact Of Child Disability On The

Family. Matern Child Health, 12, 679-683.

Russel, F. (2003). The Expectations Of Parents Of Disabled Children. British Journal of Special Education, 30(3), 144-150.

Sarı Yıldırım, H. (2007). Family Burden on Families of Children with Intellectual Disability.

Journal of Cumhuriyet University School of Nursing, 11(2).

Sucuoğlu, B. (1995). Assessment of the Needs of the Parents of Exceptional Children .

Turkish Journal of Child and Adolescent Mental Health 2,1, 10-18.

Sucuoğlu, B. (2009). Zihin Engelliler ve Eğitimleri [Mental Handicapped Individuals and Their Education](pp. 48-84). Ankara: Kök Publishing.

Şardağ, P. (2010). Zihinsel Engelli Çocuğu olan Annelerin Stresle Başa Çıkma Tarzları ve Aile Sosyal Desteğinin Evlilik Uyumların Yordaması[Prediction of Marital Adjustment by Ways of 
Coping With Stress and Family Social Support in Mothers of Mentally Retarded Children]. Master Thesis, Ege University, Institute of Social Sciences, İzmir.

Viner-Brown, P. I., \& K. Kim, H. (2005). Impact of Caring For Children with Special Health Care Needs on the Family; Rhode Island's Experience. Maternal and Child Health Journal, 9S(2), 59-66.

Warner, H. (2006). Living With Disability; Part 2. The Child/Family/Nurse Relationship. Paediatric nursing, 18(2), 38-43.

Wong, D. W., Chan, F., Cardoso, E. D. P., Lam, C. P., \& Miller, P. M. (2004).Rehabilitation Counseling Students' Attitudes Toward People with Disabilities in Three Social

204. Contexts A Conjoint Analysip. Rehabilitation Counseling Bulletin,47(4), 194-

\title{
Summary
}

\section{The Determination of the Needs of the Families with a Mentally Handicapped Child According to Their Mood}

\author{
Esat Sanli \\ Ondokuz Mayıs University, Turkey \\ Yasar Barut \\ Ondokuz Mayıs University, Turkey
}

Numerous domain experts who provide service to disabled individuals have focused on only disabled children for many years and the family has not generally dwelled on during this time. But today, it is more clearly seen that meeting the needs of family means meeting the needs of the child. The families may reveal different sensual reactions according to their children's special condition. In case it is known whether these sensual reactions affect their requirement areas and the intensity of their needs, the quality of the given assistance can be increased.This research was made to determine which requirement areas are affected by the mood of parents with a mentally handicapped child attending special education and rehabilitation centers and the level of it.The population of this research consists of the families whose mentally handicapped children attend special education and rehabilitation centers inside the Samsun provincial border in 2011-2012. The families of 443 mentally handicapped children who attend 14 special education and rehabilitation centers in Samsun city center, Çarşamba and Bafra districts were chosen via simple random sampling technique. In this research, Family Needs Assesment Survey (FNAS), which was developed by Bailey and Simeonsson, adapted into Turkish by Sucuoğlu, revised by Cavkaytar and friends, was used as the data collection tool. FNAS and the personal information form which was developed by the researcher were applied to the families of 443 mentally handicapped children who attend special education and rehabilitation centers. The average points of the parents they got from four subscales differ according to their mood.

Key words: Mentally handicapped child, rehabilitation centers, simple random sampling technique, Family Needs Assesment Survey (FNAS). 